\title{
Rabies in an Arctic fox on the Svalbard archipelago, Norway, January 2011
}

I Ørpetveit ${ }^{1}$, B Ytrehus ${ }^{1}$, T Vikøren¹, K Handeland ${ }^{1}$, A Mjøs², S Nissen³ ${ }^{3}$. H Blystad ${ }^{4}$, A Lund (arve.lund@vetinst.no) ${ }^{1}$

1. Norwegian Veterinary Institute, Oslo, Norway

2. Norwegian Food Safety Authority, Oslo, Norway

3. Longyearbyen hospital, Longyearbyen, Svalbard, Norway

4. Norwegian Institute of Public Health, Oslo, Norway

Ørpetveit I, Ytrehus B, Vikøren T, Handeland K, Mjøs A, Nissen S, Blystad H, Lund A. Rabies in an Arctic fox on the Svalbard archipelago, Norway, January 2011. Euro Surveill. 2011;16(7):pii=19797. Available online: http://www.eurosurveillance.org/ViewArticle.aspx?Articleld=19797

We report a case of rabies in an Arctic fox. In January 2011 a fox attacked dogs belonging to a meteorological station in the Svalbard archipelago, Norway. Rabies virus was detected in the fox's brain post-mortem. The dogs had been vaccinated against rabies and their antibody levels were protective. Post-exposure prophylaxis was administered to staff at the station. Rabies vaccination is recommended for inhabitants and visitors to the Arctic who may be in contact with wild animals.

\section{Case of rabies in an Arctic fox}

On 4 January 2011 an Arctic fox (Vulpes lagopus) attacked a group of four dogs on the small island of Hopen $\left(76.30^{\circ} \mathrm{N}, 25.01^{\circ} \mathrm{E}\right)$ located in the south-eastern part of the Svalbard archipelago, Norway, in the Arctic.

The dogs belong to the staff of four persons operating a meteorological station on this island and are primarily kept to warn against and scare off migrating polar bears. During the attack, two dogs were bitten before they killed the fox (Figure). The staff suspected that the animal might be infected with rabies virus because of its aggressive behaviour. No staff had been bitten by the fox, however three had handled the dead body.

The Governor of Svalbard was immediately informed about the incident. After consultation with the competent authority, the Norwegian Food Safety Authority, the Governor approved helicopter transport of the carcass to the main island of Svalbard, Spitsbergen, and from there to the Norwegian Veterinary Institute (NVI) in Oslo, which is the reference laboratory for animal rabies in Norway.

\section{Investigations undertaken}

A necropsy of the fox was performed at the biosafety level 3 laboratory of NVI and brain samples were collected for lyssavirus examination. The fox was a thin, young adult male. Its eyes lay deep in the orbit and the nictitating membranes showed pronounced protrusion. The stomach contained small amounts of seaweed and white hairs. The content of the small intestine was sparse and the colon contents were dark and watery, indicating diarrhoea.

Seven samples from different parts of the brain were analysed by direct fluorescent antibody test (FAT) and reverse transcription polymerase chain reaction (RT-PCR). All samples were positive for rabies virus. A 571 base pair fragment of the viral nucleoprotein (N) gene was sequenced: a BLAST search against the GenBank database showed $99 \%$ identity with rabies virus isolates from the Arctic [1,2]. The results were confirmed by the Friedrich-Löeffler Institute, Germany, the World Organisation for Animal Health (OIE) reference laboratory for rabies.

\section{Measures implemented}

On the evening of 7 January health officials at the Longyearbyen hospital at Svalbard were informed that the fox was infected with rabies. The staff at the meteorological station had not previously been vaccinated against rabies. The dogs had been vaccinated (a mandatory requirement), but as their rabies-specific antibody titres were unknown, and given the risk of staff members being bitten when handling the animals, it was decided that post-exposure prophylaxis should be administered to all four staff. Human rabies immune globulin was transported overnight from the mainland. After consultation with the Norwegian Institute of Public Health, the following regime was adopted: On the first day of immunisation (four days after the incident) the person having been in closest contact with the dead fox was given one dose of immunoglobulin plus one dose of vaccine, and the other three staff members were given two doses of vaccine. This was followed by one dose after three, eight and 15 days. This regime for vaccination is in accordance with the new recommendations from the Advisory Committee on Immunization Practices at the United States Centers for Disease Control and Prevention [3] and the World Health Organization (WHO) [4].

The dogs had been vaccinated against rabies at annual intervals, with booster shots as recently as 28 
December 2010. An inactivated vaccine (Rabisin, Merial) was used, providing a protective immune response by stimulating antibody production against glycoprotein surface antigens of rabies virus. The antibody response following a booster dose normally peaks a week following injection and stays at a high level. To confirm an adequate level of antibodies, blood samples taken from the dogs on 12 January were tested by the OIEprescribed fluorescent antibody virus neutralisation assay. All the dogs had an antibody titre of $>0.5$ international units (IU)/ml (National Veterinary Institute, Uppsala, Sweden), which is the level accepted by OIE and WHO as indicating a protective response. For the dogs bitten by the rabid fox, the risk of contracting disease is considered negligible. The OIE recommends an observation period of 45 days for vaccinated dogs post exposure. The dogs at the meteorological station have therefore been isolated and contact between staff and dogs will be limited during this period.

\section{Rabies in the Arctic}

Rabies is regarded as an endemic disease throughout most parts of the Arctic, and several epidemics have been reported during the last 40-50 years in arctic Canada, Russia and Greenland [5]. The Arctic fox is the main host of the virus, and the same arctic virus variant seems to infect the Arctic fox throughout the area it inhabits. How rabies is maintained in the fox population remains largely unknown. On Svalbard, rabies was diagnosed for the first time in 1980 during an outbreak in the Arctic fox population [6]. In 1980 to 1999 , a total of 25 animals were diagnosed with rabies on the islands, including three reindeer (Rangifer tarandus platyrhynchus) and one ringed seal (Pusa hispida). No further cases had been reported until the present case. Mainland Norway remains rabies free.

\section{Concluding remarks}

Rabies occurs sporadically in wildlife in the Arctic. Surveillance of the disease is important to obtain

\section{FIGURE}

A rabid Arctic fox attacks a dog at Hopen meteorological station, Svalbard, Norway, January 2011

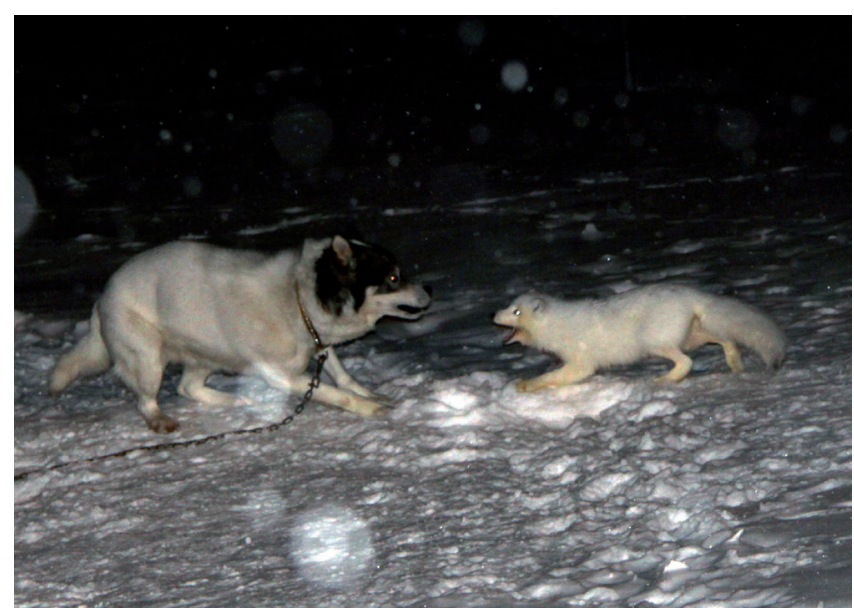

more information about the epidemiology and risks of human and animal exposure. Dead foxes and other animals should not be touched with naked hands, but secured in a plastic bag for laboratory examination. Any dead animal should be reported immediately to the Governor of Svalbard. Rabies in foxes is not characterised by specific gross lesions at necropsy, but signs of dehydration, atypical stomach content, low food intake and low body weight should raise suspicion of this disease and especially if the animal had shown aggressive behaviour.

The Governor maintains a register of all domestic animals in the islands and they are mandatorily vaccinated against rabies as a prophylactic measure to protect the resident animal population and reduce the risk of human exposure. Transmission to humans has never been documented. However, visitors to the region, particularly hunters and wildlife explorers, should be aware of the risk of rabies. Given the risk, rabies vaccination is recommended for people in the region who may be in contact with wild animals. In this remote and sparsely populated area, it is particularly important that immunoglobulin and vaccines are readily available, to keep the time between exposure and immunisation to a minimum. Following this incident, rabies immunoglobulin and vaccine are now stored at the local hospital in Longyearbyen. In addition, local health authorities at Svalbard will more actively promote pre-exposure rabies vaccination to persons at risk.

\section{Acknowledgements}

The skilled technical assistance of Marthe Opland, Tone Kofstad and Faisal Suhel, Norwegian Veterinary Institute, is gratefully acknowledged. Harald Os, Norwegian Food Safety Authority, Karin Rønning, Norwegian Institute of Public Health, and Kari Schrøder Hansen, Longyearbyen hospital, have all provided valuable information and comments on the paper.

\section{References}

1. Kuzmin IV, Botvinkin AD, McElhinney LM, Smith JS, Orciari LA, Hughes G], et al. Molecular epidemiology of terrestrial rabies in the former Soviet Union. J Wildl Dis. 2004;40(4): 617-31.

2. Nadin-Davis SA, Casey GA, Wandeler AI. A molecular epidemiological study of rabies virus in central Ontario and western Quebec. J Gen Virol. 1994;75(Pt 10):2575-83.

3. Centers for Disease Control and Prevention (CDC). Use of a reduced (4-dose) vaccine schedule for postexposure prophylaxis to prevent human rabies. [Accessed 15 Feb 2011]. Available from: http://www.cdc.gov/rabies/resources/acip_ recommendations.html

4. Rabies vaccines: WHO position paper. Wkly Epidemiol Rec. 2010;85(32):309-20. Available from: http://www.who.int/ wer/2010/wer8532.pdf

5. Mørk T, Prestrud P. Arctic rabies--a review. Acta Vet Scand. 2004;45(1-2):1-9.

6. Odegaard OA, Krogsrud J. Rabies in Svalbard: infection diagnosed in arctic fox, reindeer and seal. Vet Rec. 1981;109(7): 141-2.

Photo: Ragnar Sønstebø, Hopen meteorological station. 